\title{
Introduction: \\ The Founding of the World Jewish Congress
}

The inaugural convention of the World Jewish Congress (WJC), which was attended by 280 delegates from 32 countries, took place in Geneva in August 1936. While the organization itself was new, its ideological roots lay in the transformations experienced by the Jewish communities in the United States and Europe in the wake of World War I, and in the Balfour Declaration. The purpose of the WJC was twofold: to continue in the tradition of the American Jewish Congress (founded in 1918) and the Committee of Jewish Delegations (founded in 1919) to operate as a voluntary organization representing Jewish communities and organizations worldwide vis-à-vis government authorities and international bodies, and to foster the development of social and cultural life in Jewish communities around the world.

The establishment of the Congress, as well as the organizational and political activity of its institutions, was the outcome of an ideological view manifested in a wide range of speeches, journal articles, and minutes of meetings dating back to the beginning of the organization's creation. In 1933, the American Founding Committee, in conjunction with the American Jewish Congress, distributed an open letter informing the Jewish public in the United States of the intention to found the organization, and explaining the ideological position that had driven the initiative. ${ }^{1}$ Its lead founder and first president was the Reform rabbi Stephen S. Wise, among the foremost Zionist leaders in the United States and an active supporter of the Democratic Party. ${ }^{2}$ The founders proceeded upon the assumption that the condition of world Jewry in 1933 unequivocally demonstrated to Jews

1 Letter of the Founding Committee of the World Jewish Congress, October 26, 1933, documents of the World Jewish Congress at the Jacob Rader Marcus Center of the American Jewish Archives, Cincinnati, OH. Manuscript collection 361, box A40, folder 4 (hereafter AJA, 361 A40/4).

2 For a general account of the WJC see Leon A. Kubowizki, Unity In Dispersion: A History of the World Jewish Congress (New York, 1948); and Isaac I. Schwarzbart, 25 Years In the Service of the Jewish People: A Chronicle of Activities of the World Jewish Congress August 1932-February 1957 (New York, 1957). Among the other leading figures who actively participated in the founding of the organization were the Zionist leader Leo Motzkin, and Louis Lipsky, the former chairman of the American Zionist Organization. For an appreciation of the dominance of the United States, see letter from Nahum Goldmann to Eliezer Kaplan, Treasurer of the Jewish Agency at the time, January 11, 1943, Central Zionist Archive in Jerusalem, record group Z-6, file 2755 (hereafter CZA, Z-6/2755). On the organization's total financial dependence on the United States, see letter from Nahum Goldmann to Stephen Wise, December 17, 1936, AJA, 361 A1/1. For an example of the voluminous works on Wise, see Melvin I. Urofsky, A Voice That Spoke for Justice: The Life and Times of Stephen S. Wise (Albany, 1982). 
and non-Jews alike that the Jewish Diaspora was a distinct entity that shared a single destiny. The drafters of the letter believed that the signing of the Balfour Declaration made it possible for international recognition of the need for the establishment of a national home in Palestine to go hand in hand with recognition of the existence of a Jewish entity in the Diaspora - that the national home in Palestine and the Jewish Diaspora were two sides of the same coin. In their view, these constituted two parallel lines of development of Jewish nationality, which coexisted and nourished each other. ${ }^{3}$

The issue of Palestine resurfaced later in the letter. While the WJC leadership was well aware of the importance of Palestine in absorbing Jewish immigration, it emphasized its belief that Jewish migration from Europe to Palestine was ideologically driven, and that the new organization should therefore not engage with it, since the mission of the WJC was to find a comprehensive solution for the masses of Eastern and Central European Jews. Palestine could not, so they believed, provide an answer to the distress being suffered by Eastern European Jewry. ${ }^{4}$

The founders of the WJC were aware that the need for establishing an international Jewish organization in the mid-1930s was not self-evident, particularly in light of the existence of the Zionist movement and other philanthropic Jewish bodies that were operating in the international arena. This realization was expressed in a booklet distributed among the Jewish public in the United States in 1934. The document took the form of questions and answers and was intended both to introduce the WJC to the Jewish public and to address concerns regarding its singularity and necessity. ${ }^{5}$ The first question addressed in the booklet was "What is the World Jewish Congress?" The authors' response emphasized the democratic nature of the organization, adding that its structure would facilitate addressing the severe problems besetting the Jewish people in the 1930s. Subsequent questions referred to the uniqueness of the WJC vis-à-vis existing Jewish organizations engaged in defending the rights of Jews and in attempting to improve their economic condition. The authors asserted that the existing organizations represented only a relatively small number of Jews within the entirety of world Jewry and that, because of their undemocratic nature, they had sometimes failed to adequately represent the interests of the Jews as a whole. Furthermore, activities directed at improving the economic circumstances of the Jews had been primarily philanthropic in character, whereas the WJC would seek to radically transform the global Jewish economic structure. ${ }^{6}$

3 Letter of the Founding Committee, October 26, 1933, AJA, 361 A40/4.

4 Ibid.

5 Questions and Answers Booklet, 1934 (no precise date given), AJA, 361 A40/4.

6 Ibid. 
The uniqueness of the WJC in relation to existing bodies was likewise highlighted in the question that presented issues the organization planned to tackle in future. The answer covered a wide range of issues-from Jewish migration, through the rehabilitation and amelioration of the condition of Jews unable to migrate, to the struggle against anti-Semitism and for the Jews' basic human rights. The authors noted that the issue of migration to Palestine was the responsibility of the Jewish Agency, and that the WJC would engage in this area only in order to support and assist the activity of that body. The authors thus laid out a singular world view (that would be spelled out more clearly later in the document), in which the Congress was not opposed to the Zionist enterprise in Palestine, but did not regard this as its overriding concern. ${ }^{7}$

The objectives presented by the founders to the WJC were far-reaching and ambitious-and likely to raise doubts as to its ability to achieve them. In their response to questions along these lines, the authors stated that, unlike the Jewish bodies that had operated thus far, the institutions of the WJC would prepare a comprehensive collection of data and information relating to world Jewry in order to facilitate correct and effective action in relation to the global political system. The founders believed that the attack on the rights of European Jewry and Nazi propaganda directed against the Jews would serve to intensify the pressure on the League of Nations to find appropriate solutions to the distress of the Jews. Given the current crisis of European Jewry, the efforts of the public relations campaign that the WJC intended to wage, combined with the joint action undertaken by all the Jewish organizations and with the activity within the League of Nations, were likely to produce a future solution and to improve the situation of the Jews worldwide. ${ }^{8}$

The renowned philosopher and sociologist Professor Horace M. Kallen affirmed the necessity of founding the World Jewish Congress when he addressed its preparatory convention in Geneva in 1934. Kallen argued that the processes of globalization and democratization had destroyed the Jewish solidarity of the Middle Ages, and that it was essential to establish the WJC in order to rebuild it. The vital need for the organization was underscored, he believed, by the anti-Jewish propaganda emanating from Germany as well as world-wide trends toward racism and totalitarian regimes. It was the Jews who were suffering most from these trends; consequently, it was the duty of Jews worldwide to oppose them with renewed vigor. A democratic Jewish congress was, therefore, the essential response. Kallen stressed that the Jewish philanthropic organizations that had arisen in the wake of the emancipation were not confronting the problems facing

7 Ibid.

8 Ibid. 
world Jewry. Ad hoc solutions that provided a temporary material response to the hardships experienced by Jews could not resolve the Jewish problem and in a certain sense exacerbated it, since they offered local, short-term measures, thereby postponing more comprehensive solutions. ${ }^{9}$

The tendencies manifested in the letter of 1933 and in Kallen's address were reinforced in a memorandum submitted by the directorate of the WJC to the institutions of the League of Nations in $1936 .^{10}$ The memorandum reviews the traditional Jewish support for peace and international cooperation, and underscores the organization's contribution to the struggle for these ideals. The memorandum was intended to secure the League of Nations' support for the rights of minorities in general and of the Jews in Europe in particular, and to position the Congress as the exclusive representative of the Jewish people in the Diaspora. For this reason, the members of the Executive Committee of the WJC, who authored the document, stressed that the organization represented the Jews of the Diaspora and was fighting for minority rights, but likewise supported the Jewish community in Palestine and was working to stabilize the mandated government there. ${ }^{11}$ Thus they clarified their world view: advocating a complex Jewish reality that combined a Jewish national existence in the Diaspora with the founding of a national home in Palestine. The WJC was the ultimate manifestation of the dual reality they presented, and through its very existence and modus operandi could address the complex nationalism encompassing both the Jewish Diaspora and the Land of Israel. Stephen Wise, president of the WJC, developed the argument that the organization was fulfilling an essential purpose. According to Wise, the establishment of a democratic Jewish organization prepared to take robust action on behalf of world Jewry was a vital matter because of the situation of European Jewry. He maintained that the founding of the WJC constituted a historic turning point, the full significance of which lay in the establishment of a democratic Jewish organization precisely at a time of deep crisis. ${ }^{12}$ Wise went on to describe the democratic voting process whereby each Jewish home in the United States would receive a voter card for the price of ten cents. The election was to be super-

9 Horace Kallen at the preparatory convention of the WJC, August 20-23, 1934 (no precise date), AJA, 361 A40/5.

10 Memorandum of the Executive Committee of the WJC submitted to the League of Nations on December 16, 1936, AJA, 361 A1/2.

11 Memorandum of the Directorate of the World Jewish Congress to the League of Nations, AJA, $361 \mathrm{~A} 1 / 2$.

12 Open letter from Wise to the Jews of America in the context of elections to the World Jewish Congress, March 1938 (no precise date given), AJA, 361 A9/4. For an address in a similar vein, see the public declaration by Louis Lipsky, May 9, 1938, ibid. See also letter from Wise to Rabbi Joseph Rantz of Louisville, Kentucky, December 1, 1941, AJA, 361 C68/13. 
vised by a national election committee that would determine the number of delegates that each community would elect to the Congress's institutions. Later in the letter Wise underscored in large print that the appropriate response to the attack on millions of Jews around the world by anti-democratic forces was the mass participation in this democratic process by Jews in the United States, which would signify the commitment on the part of America's Jews both to the struggle for democracy and on behalf of the Jews of the world. ${ }^{13}$

It should be noted here that the WJC defined itself as an international organization, although, in fact, it operated as an American Jewish organization. Its headquarters were located in the United States and its European and South American offices were financed by American sources and reported on their activities to the Congress Directorate in the New York. In 1939, Nahum Goldmann, co-founder of the WJC, believing that the only monetary source for the organization's activity in Europe was to be found in the United States, stressed that the initiative for founding the Congress had emanated from America, therefore placing greater responsibility on American Jewish leaders, and on Wise in particular, to muster the resources required to ensure the organization's continued functioning in light of the grave situation of European Jewry. ${ }^{14}$ This state of affairs had prevailed prior to World War II and naturally took a turn for the worse following its outbreak. Indeed, an official announcement by the WJC explained that the organization's headquarters had been relocated to New York in the wake of the outbreak of war. ${ }^{15}$ This announcement divulged that, unlike in the past, the branches of the Congress in London and Geneva would become departments whose sole function would be to take care of the Jews of Europe. The European offices would report to headquarters in New York, and the organization's policy would be determined in New York alone. It was clearly stated that any significant activity by the branches in Europe required prior authorization from New York, and that prominent European functionaries would move from Europe to the United States as part of the organizational transformation. The authors of the document explained that the organizational change was essential, given that the United States was a democratic country and because of the relative power wielded by its Jewish community, which made the American arena the only location in which significant Jewish activity could be conducted in the early 1940 s. $^{16}$

13 Wise, open letter, March 1938, AJA, 361 A9/4.

14 Letter from Goldmann to Wise, May 30, 1939 (sent from Paris), AJA, 361 A9/6.

15 Official announcement of the directorate of the World Jewish Congress in New York, August 1, 1940, AJA, 361 A5/2.

16 Announcement of the Directorate of the World Jewish Congress, August 1, 1940, ibid. 
A significant factor that facilitated the activity of the WJC in the United States and enhanced its capacity to operate in the American sphere was the fact that it was virtually identical to the American Jewish Congress. Stephen Wise served both as president of the American Jewish Congress and as chairman of the Executive Committee of the WJC, a situation that symbolized the organizational similarity of the two bodies, as well as the fact that the American Jewish Congress was the dominant body within the WJC, providing it with financial support and political backing. ${ }^{17}$ In this vein, Arieh Tartakower, who served as chairman of the organization's Welfare and Relief Committee during World War II and subsequently became Professor of Sociology at the Hebrew University, defined the WJC as an American organization. Describing the power of the American Jewish community, he wrote: "This element determined, as mentioned, the status and modus operandi of the Congress, which itself now became to no small degree an American institution with the head office to New York, and once the best of the leadership had assembled there, included a large section of the former European leadership". ${ }^{18}$

Studies of the American Jewish leadership of the 1930s and '40s deal extensively with top WJC executives, whose activities are closely examined and often severely criticized. ${ }^{19}$ Such criticism primarily addresses the issue of assistance to the persecuted Jews of Europe. There exists a huge volume of scholarly literature on the inability of the American Jewish leadership to effect the rescue of Jews during the Holocaust. ${ }^{20}$ The complexity of this topic is well expressed by Henry

17 See the memorandum of the directorate of the World Jewish Congress regarding the Congress's activity since the outbreak of war, no author given, May 31, 1940, AJA, 361 A5/1.

18 A native of Galicia, Arieh Tartakower immigrated to the United States in 1939 and served as Chairman of the Congress's Welfare and Relief Committee as well as Deputy Director of the Institute of Jewish Affairs. He immigrated to Palestine in 1946, was appointed Professor of Jewish Sociology at the Hebrew University and continued to function within the World Jewish Congress. Among other roles, he headed the organization's cultural department and served as Chairman of the Congress's Israel wing. See Arieh Tartakower, Manuscript on the World Jewish Congress (which did not appear in book form), undated, CZA, C-6/352 Tartakower furthermore emphasized the structural unity of the World Jewish Congress and the American Jewish Congress: "With the transfer of the Congress's head office to New York, it began in any case to cooperate with the American Jewish Congress. The two principal institutions of the Congress at that time, the Relief Committee for Jewish War Victims and the Institute of Jewish Affairs were in effect run jointly, the former de facto and the latter also formally ... [deletion by the author]. Dr. Wise directed both of these institutions.” See Tartakower, ibid., 7.

19 For a prominent example of these, see David S. Wyman and Rafael Medoff, A Race Against Death: Peter Bergson, America, and the Holocaust (New York, 2002), 29-30, 230-231.

20 See, for example, David S. Wyman, The Abandonment of the Jews: America and the Holocaust, 1941-1945 (New York, 1984); Rafael Medoff, The Deafening Silence (New York, 1987). For 
Feingold, who stressed that discussion of American Jewry and the Holocaust should take into account the broad context of these leaders' exceptional awareness of the fate of Jews in other cases, as well as the constraints and difficulties they faced during World War II. ${ }^{21}$

Indeed, one cannot ignore the sense of uneasiness and the questions that emerge from the study of American Jewish leadership at the time of the Holocaust. ${ }^{22}$ Nevertheless, letters and documents of the period that address the activity of this leadership enable us to add a further layer to the study of the American Jewish elite (including the WJC leadership) at the time of the Holocaust, thereby enhancing our understanding of the array of factors that influenced the activity of the WJC leadership at this most critical juncture for world Jewry. This book addresses the similarities between the World Jewish Congress and the Zionist movement. The fact that the WJC was an organization that identified with the ideology and actions of Zionist movement during the 1930s and '40s raises serious questions about the motives of its founders, most of whom were members of the World Zionist Movement, in establishing a separate Jewish organization. Initial findings suggested that there was no need to found the Congress in 1936, yet a number of underlying motives subsequently emerged. These are linked to the manner in which the Jews functioned as a minority group in the United States during World War II, and to their desire to engage in ethnic politics (which represent the narrow interests of a minority group), thereby exerting influence at the national political level.

The letters and speeches of WJC leaders presented here reveal the tremendous hardships encountered by the American Jewish community and the representative bodies of the Jewish people during and after World War II as they strove as a minority within American society to rescue Jews, care for the refugees, and realize the objectives of the Zionist movement-namely the founding of a Jewish state after the war. These difficulties were among the factors that led them to moderate their political demands, curtail overt protests, and engage instead in covert activities of which the broad Jewish community remained unaware.

an extensive list of like-minded studies, see Gulie Ne'eman Arad, “Cooptation of Elites: American Jewish Reactions to the Nazi Menace, 1933," Yad Vashem Studies 25 (1996): 32-33. See also Allan J. Lichtman, FDR and the Jews (Cambridge and London, 2013; hereafter: Breitman and Lichtman, $F D R)$.

21 Henry L. Feingold, Bearing Witness: How America and Its Jews Responded to the Holocaust (New York, 1995), 14-16, 205-76; Henry L. Feingold, "Was there Communal Failure? Some Thoughts on the American Jewish Response to the Holocaust," American Jewish History 81 (1993): 60-80.

22 Robert D. Shapiro, A Reform Rabbi in the Progressive Era: The Early Career of Stephen S. Wise (New York, 1988), 422-423. 
Ostensibly, the founders of the WJC were seeking to promote democratization of Jewish life and to step up activity designed to rescue Jews and to oppose Nazi Germany. In fact, however, they cooperated with other Jewish elites and with the U.S. administration with a view to moderating the American Jewish reaction to the Holocaust, although they were fully aware of the dimensions of the persecution. Such patterns of activity generated an essential disparity and intrinsic tension between the overt political activity of the WJC leadership during the war years in the United States and its covert activity, which, under the circumstances, was confined to rendering local assistance to persecuted Jews and failed to exert a meaningful influence on the United States Administration. This book serves to show that the wish of the heads of the WJC to soften the outward reaction of the American Jewish public to the Holocaust can be understood in light of the changes that had occurred in the socio-economic status of Jewish Americans, as well as changes in the public and individual status of the WJC leaders within the overall political and social system the United States during the 1940s.

This by no means indicates a wish to detract from the real difficulties and the serious failings of the World Jewish Congress during the thirties and forties. Yet despite these failings, it should be stressed that the heads of the organization, particularly Executive Chairman Stephen Wise and Executive Committee Chair Nahum Goldmann, played an important role in the overt and covert contacts with the administration concerning various issues related to world Jewry and the Zionist movement, and acted on behalf of the Jewish Congress to shape the reaction of the American Jewish public to the Holocaust according to their outlook.

Wise and Goldmann's activity in the United States during the 1930s and '40s may be fully appreciated by considering Wise's status within the Democratic Party and the impressive web of contacts with key figures in American politics that Goldmann wove after arriving in the country as a refugee in the early 1940s. It was Stephen Wise, a Reform rabbi, among the founders of the American Zionist movement and one of its most influential leaders until the mid-1940s, who in fact initiated the establishment of the WJC. He worked tirelessly toward this objective beginning in 1932, and was elected president of the organization at its inaugural convention in 1936. In addition to this activity, Wise was the president of the American Zionist Organization from 1936 to 1938, and chairman of the Zionist Emergency Committee in the United States from 1943 to 1945. This book does not aspire to be a biography of Wise, but rather to demonstrate the key role he played in the founding of the WJC and in its activity.

Wise (1874-1949) was born in Budapest, Hungary, and grew up in New York. He belonged to a family of Orthodox rabbis, but his religious outlook differed from theirs. He joined the Reform movement and turned the Reform rabbi's sermon into a veritable cult in his community. His political power was focused in 
New York, where he engaged in his public activity at the Free Synagogue, which he himself founded in 1907 after turning down the position of rabbi at the prestigious Reform synagogue Temple Emanu-El because he objected to the demand of the community leadership that they be allowed to censor his sermons. One factor that made Wise an outsider in the Reform movement was his disagreement with the anti-Zionist attitude that reigned within it. The control exercised by the non-Zionists at the Hebrew Union College (HUC) in Cincinnati was among the central factors that in 1920 led Wise to found an independent rabbinical seminar, the Jewish Institute of Religion (JIR), alongside his New York synagogue. ${ }^{23}$ Wise was deeply involved in American life and politics. Social and political events played a large part in his sermons as a Reform rabbi as well as in the articles he wrote for the journal Opinion, which he founded in 1931. Among other issues, he campaigned for improved conditions for industrial workers, against corruption in New York's city hall, and for the rights of African Americans. Wise's public activity in the national arena was not confined to social issues. At the outset of his career he supported the Democrat Woodrow Wilson. Wise was a respected member of the national Democratic Party and of the Democratic establishment of New York, and remained a party faithful throughout his life. His connections to President Franklin Delano Roosevelt-forged when he supported Roosevelt's successful candidacy for the office of governor of New York in 1928-were of great importance. Wise declined to support Roosevelt's first attempt to win the Democratic nomination for president because he believed that as governor, Roosevelt had not combated corruption in New York, but he consistently supported him from 1936 onward, primarily because of the president's New Deal policy. ${ }^{24}$ Between 1944 and 1946, Wise's position of eminence in the American Zionist leadership was gradually eroded because of the struggle he waged against Abba Hillel Silver, a Reform rabbi and the most prominent American Zionist leader in the late 1940s. Roosevelt's death in 1945 further weakened Wise's political stature; he lost his close connection with the White House and was unable to establish a similar relationship with President Harry S. Truman. As he was edged out of the American Zionist leadership, Wise devoted himself increasingly to activity on behalf of the WJC.

23 The American Zionist Emergency Council was composed of representatives of the Zionist organizations in the USA and conducted Zionist activity there during World War II. The Council was founded in 1939 according to a resolution adopted by the Zionist Congress, and was initially named the Emergency Committee for Zionist Affairs. On the Emergency Council, see Doreen Bierbrier, "The American Zionist Emergency Council: An Analysis of a Pressure Group," American Jewish Historical Quarterly 1 (1970): 82-105.

24 For a general information about Wise, see Stephen Samuel Wise, Challenging Years: The Autobiography of Stephen Wise, 1874-1949 (London 1951). 
At the time that Wise was actively promoting the founding of the WJC, Nahum Goldmann's stature in the World Zionist Organization was growing. He came to particular prominence following the $17^{\text {th }}$ Zionist Congress held at Basle, Switzerland, in 1931, where he acted to remove Haim Weizmann from the presidency of the Zionist organization. ${ }^{25}$ Goldmann's involvement in Zionist circles in the United States (to which he paid his first extended visit after the $17^{\text {th }}$ Zionist Congress) played an important role in his becoming a leading Zionist activist. One of the noteworthy aspects of his activity in America was the particularly close political and personal connection that he forged with Wise. ${ }^{26}$ Goldmann identified with Wise's objectives in both the American and the Zionist arenas, and worked alongside him as one of his longstanding associates. ${ }^{27}$ Since Goldmann, while still in Europe, acceded to the rank of Zionist leader just as his connection with Wise was growing closer, he participated in the founding of the World Jewish Congress. As part of his extensive activity in this cause, he set out to persuade the representatives of Jewish communities in Europe and in South America to join the enterprise, and took part in preparing the inaugural convention of the new body, at which he delivered one of the principal speeches. He rapidly became a leading figure in the WJC, initially in Europe and then in the United States, to which he immigrated in June 1940. Goldmann's entry to the United States was facilitated by Wise, who officially invited him to take part in the Congress's activity in New York. In his letter, Wise explained that Goldmann's presence in the country was vital to the effort on behalf of European Jewry and to the undertaking of preparations for presenting the Jewish issue to the peace conference that would convene upon the ending of the war. Wise clarified that Goldmann was expected to remain in the United States for some time; therefore, his wife and children were included in the invitation. ${ }^{28}$ Goldmann succeeded Wise as president of the World Jewish Congress in 1949, remaining in the position until his resignation in 1977. The role constituted an important anchor for his overall political and public activity. ${ }^{29}$

25 Nahum Goldmann, The Autobiography of Nahum Goldmann: Sixty Years of Jewish Life (New York, 1969), 115-118.

26 Nahum Goldmann, "Dr. Stephen Wise," in On the Paths of My People [in Hebrew] (Jerusalem, 1968), 217-229. For a further example of the close bonds between Wise and Goldmann during the 1940s, see Wise's energetic support of Goldmann among United States Zionist circles in a letter from Wise to Goldmann, November 18, 1946, CZA, Z-6/98.

27 See, for example, the letter from Goldmann to Wise, August 10, 1944, CZA, Z-6/2759.

28 Goldmann, The Autobiography, 192-193. See also Wise's letter to Goldmann, February 5, 1940, AJA, 361 A27/2.

29 Nahum Goldmann, “The Congress at Work," in The Jewish Paradox (London, 1978), 54-55. 


\section{The World Jewish Congress, the Zionist Movement, and their Parallel Paths}

During the years he spent in the United States, Goldmann held a wide range of positions in Zionist and Jewish organizations simultaneously. While a number of senior Zionist figures engaged in similar public activity, the multiple functions performed by Goldmann and his associates in the WJC leadership endowed them with singular power. ${ }^{30}$ An anecdote that reflects this state of affairs relates to a request Goldmann submitted to the New York Telephone Company in the summer 1943 that they must immediately install a main phone line and two extensions in his new apartment in Manhattan. In support of his application Goldmann reviewed his various roles, among them that of chairman of the WJC's administrative committee, his membership on the Executive Committee of the Zionist Organization, and the position of chairman of the Jewish Agency office in Washington, all of which he occupied at the same time. Goldmann claimed that in order to fulfill these functions he had to maintain ongoing and reliable contact with senior administration officials, with the media, and with Zionist representatives worldwide, and that this entitled him to an additional phone line. ${ }^{31}$

As mentioned previously, it was not only Goldmann and Wise who occupied multiple posts at the same time in the Zionist movement and in the WJC, but other central figures in the WJC as well. Most of those elected to key positions at the inaugural convention of the organization were leading Zionist activists. Louis Lipsky, for example, ex-chairman of the American Zionist Organization and its current president, was elected chairman of the Jewish Congress alongside his position as member of the Zionist Executive Committee and Judge Julian Mack, honorary president of the WJC in 1936, had been president of the American Zionist Organization in 1918. Examination of the curriculum vitae of deceased founders of the Congress who were eulogized and commemorated in speeches delivered at WJC conventions reveals that many of the organization's broad circle of activists likewise operated in parallel in the Zionist movement. ${ }^{32}$ These data

30 On this phenomenon, see Tuvia Friling, An Arrow in the Dark: Ben Gurion, The Yishuv Leadership, and Attempts at Rescue During the Holocaust (Jerusalem, 1998), 8-9 (Hebrew; hereafter: Friling, Ben Gurion).

31 Goldmann's letter to the New York Telephone Company, June 3, 1943, CZA, Z-6/18.

32 Nahum Goldmann, memorial speeches at the Preparatory Council and the Inaugural Convention of the World Jewish Congress [in Hebrew], August 23, 1934 and August 10, 1936, CZA, Z-6/2273. For general background on this issue, see Mordechay Figowitz, "The American Jewish Background to the Founding of the World Jewish Congress: Shaping Policy and Organizational Patterns Between the Zurich Convention in 1927 and the Geneva Convention in 1932” [in Hebrew] (M.A. dissertation, Haifa University, 1977), 91. 
raise the above-mentioned question about the considerations that led Stephen Wise, Nahum Goldmann and their associates to found the World Jewish Congress alongside their activity in the Zionist movement.

This question becomes more pertinent upon considering certain further facts that reinforce the impression that the new organization focused on precisely the same issues with which the existing organization was already engaged. For example, one of the WJC's fundamental objectives was to care for Jewry worldwide, but especially for the Jews of Eastern Europe. Perusal of the ideology and the actions of the Zionist movement during the 1930s reveals that it had already taken upon itself the task for which the new organization was established. The founders of the WJC, who were also leading Zionist activists, were well aware of this duplication of effort, and of the existence of other non-Zionist bodies that were primarily concerned with caring for Jews in countries around the world. ${ }^{33}$ Goldmann himself noted that the Zionist movement was the driving force in the organization of Jewish communities in the Diaspora and in reviving Jewish culture. He stressed that the Zionist movement was engaging in the rescue of Jews in distress more than any other Jewish body. ${ }^{34}$ As early as 1933 , as the initial steps were being taken to found the WJC, Stephen Wise remarked that many within the Zionist movement, particularly those in the Labor Zionist movement, opposed the establishment of the organization because they believed that the Congress's future activity on behalf of world Jewry would harm the Zionist movement and erode its status as the movement that represented all Jews worldwide and which had made caring for Jews in the Diaspora one of its fundamental objectives. ${ }^{35}$ The heads of the WJC, however, countered with an array of arguments designed to justify the existence of the Congress alongside the Zionist movement. They maintained that although the Zionist movement had decided at the Helsinki Conference of 1906 to engage in "present-day work among the Jews in the Diaspora," it had been unable to undertake this task, most of its effort being devoted to activity in Palestine. They believed that there was a need for an international Jewish organization that would complement the activity of the Zionist movement, receive its support, and promote its aims. ${ }^{36}$

33 See, for example, Yehuda Bauer, My Brother's Keeper: A History of the American Jewish Joint Distribution Committeee, 1929-1939 (Philadelphia, 1974).

34 Lecture delivered by Nahum Goldmann at a convention of the World Jewish Congress in Atlantic City in November 1944 (precise date not given), CZA, Z-6/2248.

35 Wise's oral report on his visit to Europe, submitted to the Executive Committee of the World Jewish Congress, September 23, 1933, AJA, 361 A1/9.

36 Kubowizki, World Jewish Congress, 67, 14-17. 
This explanation does not dispel the questions regarding the separate existence of the World Jewish Congress, which are sustained by the words of Wise's biographer Melvin Urofsky. Defining the WJC as an organization with a pro-Zionist orientation, Urofsky explicitly addressed the problematic issue of its existence alongside the Zionist movement. ${ }^{37}$ In his assessment, the WJC did not turn into an alternative to the Zionist movement, and its leaders continued to serve in parallel with central positions in the Zionist movement in the United States and worldwide. Their ideological manifesto and political programs were founded on support for the establishment of a Jewish state in Palestine, and they publicly declared their close cooperation with the Jewish Agency. ${ }^{38}$ These statements throw some doubt on the assertion that the WJC had been established as an international Jewish organization that would be able to operate on behalf of world Jewry while adapting its activity to American conditions. In fact, however, the continuing membership of the heads of the WJC in the Zionist movement was more likely to reinforce rather than mitigate such allegations of dual loyalty.

While the heads and founders of the WJC did indeed underscore their intention to cooperate with the Zionist movement, it may have been assumed that the founding of an organizational body alongside the Zionist movement and in competition with it would lead to friction between the two organizations. Such tension did, indeed, occur as can be seen in a 1941 correspondence between Nahum Goldmann and Arthur Hantke, director of the head office of Keren Ha-Yesod in Jerusalem (one of the Zionist movement's principal institutions), concerning which organization's fundraising appeals controlled donations from South America.

In this correspondence and in response to a memorandum that Hantke sent to the agency executive in Jerusalem, Nahum Goldmann explained that the Zionist movement had no jurisdiction over the activity of WJC since the congress was, he claimed, an independent body. Nevertheless, Goldmann stressed that, despite the Congress's "independence" and despite the financial loss it incurred because of this, the organization had allocated most of the money it had collected toward Zionist and pioneering causes, and that there was thus no justification for the struggle being waged by the Zionist bodies against the fundraising activities of the Jewish Congress. ${ }^{39}$ Hantke responded by tracing the lack of clarity and the difficulties generated by the independent existence of the WJC, and noted that it was absurd for Goldmann to be a Zionist activist and not be subject to the authority

37 Urofsky, Wise, 298-299. Regarding the Congress's pro-Zionist orientation, see also Wyman, The Abandonment of the Jews, 76-77.

38 Lecture by Nahum Goldmann at a World Jewish Congress convention, September 23, 1933, AJA, 361 A1/9.

39 Letter from Goldmann to Hantke, November 6, 1941, CZA, Z-6/2755. 
of the Zionist institutions. This state of affairs, he asserted, hindered cooperation between the two movements, harmed Zionist interests, and enabled Goldmann and his associates to conduct an independent policy through the Congress that was not necessarily compatible with the interests of the Zionist movement. ${ }^{40}$

The difficulties raised by the very existence of the WJC alongside the Zionist movement constituted the main topic of a secret letter sent to Goldmann and Wise in June 1943 by Dr. Jacob Robinson, founder of the WJC's research institute (the Institute of Jewish Affairs), the Jewish Agency's legal advisor, and subsequently the WJC's representative at UN discussions. ${ }^{41}$ Robinson's letter notes that he was writing to them precisely because they were prominent officeholders both in the Zionist movement and in the WJC, and describes the relationship between the two movements as a grave conflict. In his view, the WJC's attempt to separate its engagement with the issue of the fate of European Jewry from the issue of Palestine in order to determine an agenda separate from that of the Zionist movement had generated serious ideological and practical difficulties for the organization. ${ }^{42}$ Goldmann himself was aware of these difficulties, as he disclosed in a summation following his retirement as president of the WJC in which he wrote of the considerable constraints on cooperation between the two organizations during the entire period of their coexistence, even though the Zionist movement had officially supported the Jewish Congress. He demonstrated the intrinsic lack of clarity created by the existence of these two organizations by remarking that he himself had for many years served simultaneously as president of the World Jewish Congress and president of the Zionist movement. When the need arose to settle disagreements between the organizations, he added, he found himself talking to himself, or in his words: "Goldmann is negotiating with Goldmann." ${ }^{43}$ This situation humorously underscores the misgivings raised by the existence of the WJC as a separate organization.

In his speech at the inaugural convention of the WJC in August 1936, Wise felt compelled to explain the need to establish the organization. ${ }^{44}$ He underscored the importance of Jewish settlement in Palestine, which had proved to skeptics that the Jews were able to live as a nation in the modern day. Yet, he continued, Zionist work in the Palestinian context and traditional philanthropic activity had

40 Letter from Hantke to Goldmann, December 3, 1941, CZA, Z-6/2755. Tuvia Frilling underscored the fact that the WJC was not subject to the authority of the Jewish Agency's institutions. See Frilling, Ben Gurion, part 1, 8-9.

41 Letter from Robinson to Goldmann, March 25, 1943, CZA, A-243/73.

42 Ibid.

43 Goldmann, The Congress, 58-59.

44 Wise's speech at the inaugural convention of the World Jewish Congress, August 8, 1936, AJA, $361 \mathrm{~A} 40 / 8$. 
failed to provide adequate answers to the fundamental problems encountered by world Jewry, particularly following the Nazis' rise to power, and there was thus a need for international Jewish action along political lines. Wise asked his audience why the non-Jewish world should show interest in and fight for Jewish issues when the Jews themselves refrained from doing so. He asserted that the lack of organization among world Jewry was playing into the hands of the enemies of the Jewish people. Anticipating criticism of the patterns of action to be adopted by the Jewish Congress as an international Jewish organization, Wise stressed that the anti-Jewish campaign was an international one, and that this called for a Jewish response that would span individual states and continents. He emphasized further that the organization would not be a Jewish super-state, and that it would be a serious mistake to think of it as a Jewish parliament. A parliament, he explained, was a juridical concept, something that constituted part of the existence of a state, whereas the Congress was not a state. ${ }^{45}$

The ideas presented by Wise in his speech to the inaugural convention of the Congress found practical political expression in the report that the WJC's economic committee prepared for submission to the economic forum of the League of Nations. ${ }^{46}$ In the spirit of Wise's outlook, the authors of the document regarded themselves as representatives of the entire Jewish nation, and sought to conduct a comprehensive study of the Jews in all their locations of residence. They examined a wide variety of topics, ranging from the effect of the Nazi party's policy on the economic situation of European Jewry to a survey of the effect of World War I on the economic condition of Jews in various countries. The document was not designed to create a file of information to be used for future philanthropic activity, but rather as the beginning of a political effort to transform the economic condition of the Jews with the assistance of the League of Nations and its institutions. ${ }^{47}$ The continuous deterioration in the condition of European Jewry reinforced the conviction of the WJC leadership that the traditional philanthropic modes of activity were no longer relevant. This outlook was demonstrated at a press conference held by Nahum Goldmann at a meeting of the League of Nations Council in January $1939 .{ }^{48}$ Goldmann reviewed the plight of the Jews of Romania,

45 Ibid.

46 Memorandum of the Economic Committee of the World Jewish Congress, March 14, 1937, AJA, 361 A9/3.

47 Ibid.

48 The press conference was held on January 19, 1939 at the WJC offices in Geneva. See secret memorandum on the activity at the League of Nations Council, January 24, 1939, AJA, 361 A1/1. For a further example along similar lines, see Letter from Goldmann to Wise following the Evian Conference, July 16, 1938, AJA, 361 A27/1; and a WJC memorandum on the refugee problem, no author attributed, February 28, 1939, AJA, 361 A5/1. 
Hungary, Czechoslovakia, Poland and Germany, asserting that a problem of this magnitude could not be solved through local measures but only by means of an overall international effort. This would have to include an international program of migration supported by world-wide funding, based on recognition of Jews' civil rights. In parallel, the heads of the WJC would initiate steps within the United States to enhance the political aspects of the activity of the various Jewish organizations and create a unified political front in which the Congress would play a major role.

Louis Lipsky, one of the founders of the Congress, wrote a clandestine personal letter in this vein to Henry Monsky, president of B'nai Brith. ${ }^{49}$ Lipsky sought to set up a federation of all the Jewish organizations in the United States on the basis of democratic principles with protecting the rights of Jews as its objective. From this letter it emerges that Lipsky's overture was part of a broad political campaign that comprised the preparation of memoranda and the holding of individual meetings with a view to promoting the idea of, in the wording of the letter, a "united Jewish front." 50 Lipsky approached Monsky in person in the wake of B'nai Brith representatives' previous opposition to contacts designed to form a united Jewish front initiated by the WJC. Lipsky notes in the letter that he was approaching Monsky in the belief that good will would facilitate close cooperation among the various Jewish organizations in the United States. He drew parallels between Zionism and the activity of the WJC on behalf of protection of the rights of Jews around the world. He felt that Zionism had become an intrinsic and legitimate part of Jewish life everywhere, and that a similar process should take place regarding the struggle for equal rights for world Jewry. ${ }^{51}$

Lipsky's political activity was not conducted in a vacuum; it should be understood against the backdrop of the continual deterioration in the condition of European Jewry, as manifested in the letter written by the historian and

49 Letter from Lipsky to Monsky, June 3, 1938, AJA, 361 A9/4. For further sources addressing this issue, see a speech delivered by Lipsky in which he calls on additional Jewish organizations in the United States to join the WJC front, Lipsky speech, May 9, 1938, no location given, AJA, 361 A9/4. At the Evian Conference the Congress likewise maintained that a single Jewish body should be established to address the issue. See Congress memorandum on the topic of the Jewish Refugees, February 28, 1939, unspecified author, AJA, 361 A5/1 . Monsky would subsequently become involved in steps to form a Jewish alliance in the United States, manifested in the founding of the American Jewish Conference in 1943. See Hasia R. Diner, The Jews of the United States (Berkeley 2004), 216-217.

50 Lipsky letter, June 3, 1938.

51 Ibid. 
thinker Shimon Dubnov to the heads of the WJC. ${ }^{52}$ Reviewing the terrible plight of Europe's Jews, Dubnov related how hundreds of thousands had been deprived of their civil and human rights. Dubnov believed that since they had no realistic chances of migrating, large swathes of European Jewry were left with but two options: the bottom of the sea or the purgatory of the lands of pogroms, which included not only Germany and Italy, but also other large areas of the continent. Dubnov stressed that, unlike other groups in Europe that were subject to Nazi aggression, the Jews had no state that could protect them. He therefore called for the formation of an international Jewish defense front under the slogan "an end to silence" in order to combat the aggression and violence. In his estimation, through its delegations in Paris, Geneva and the United States, the WJC was the appropriate organization to lead this move..$^{53}$

Wise's lecture and the memorandum submitted to the League of Nations provide some evidence of the objectives of the founders of the WJC in 1936. Contemporaries and scholars alike have questioned the motivation for establishing the organization. While most of its founders regarded themselves as Zionists and some held senior positions in Zionist bodies, they believed that their Zionism was entirely compatible with their activity in the WJC. They certainly did not think that the organization was superfluous. On the contrary, they were proud to be Zionists and worked tirelessly toward the establishment of a Jewish state, while at the same time seeking to strengthen the ethnic identity of Jews in the Diaspora, in which Zionism constituted a major component. When attempting to understand the world view of Wise, Goldmann, and their colleagues in the WJC leadership, it is important to appreciate that while the WJC was defined as an international organization, it in fact operated as an American Jewish body. It is noteworthy that American Zionism developed along different lines than its European counterpart. American Zionists refrained from emphasizing migration to Palestine as a central component of their ideology and practice, and shaped their Zionism into an important element of their fabric of life within American society rather than a means toward the practical realization of migration to the Land of Israel. ${ }^{54}$ Successive generations of American Zionist leaders created an ideological and organizational foundation that enabled any American Jew who chose to be a Zionist to bridge the gap between the largely European oriented Zionist ideology and the reality of life in the United States. They actively engaged in creating

52 Letter by Simon Dubnov to the Heads of the World Jewish Congress. Declared classified and translated into English, June 14, 1939, AJA, 361 A9/6.

53 Ibid.

54 Ofer Shiff, “The Integrative Function of Early American Zionism," The Journal of Israeli History 15, no. 1 (1994): 1-16. 
a Jewish nationalism that downplayed the elements of territorial concentration and political sovereignty, opposed the concept of "rejection of the Diaspora," and underscored the moral dimensions of Judaism ${ }^{55}$ The founders of the WJC accordingly saw no contradiction between their efforts to reinforce the ethnic and national identity of Jews in the Diaspora in the wake of the Holocaust and support for the establishment of a Jewish state. On the contrary, they regarded Zionism as a political and social movement that accords fresh legitimacy and meaning to Jewish life in the Diaspora and in the United States. Zionism enables Jews to live in the modern world while maintaining their singular ethnic and cultural identity, which is of utmost importance to humanity in general and to Jews in particular. The importance of Zionism to Jewish history derives not merely from its success in founding a sovereign Jewish state, but also from the creation of new patterns of Jewish life all over the world. The shaping of a world-wide Jewish community acting as a political force with common goals and vibrant institutions was a by-product of the supreme effort on the part of world Jewry to build a national home. ${ }^{56}$

As will become evident in the forthcoming chapters, apart from the ideological dimension, the founding of the WJC enabled its leaders, especially Stephen Wise and Nahum Goldmann, to conduct political and community activity within the United States independent of the Zionist institutions worldwide. This was something of considerable importance particularly in view of the growing political and public power of the American Zionist leader Abba Hillel Silver during the 1940s, with whom Wise and Goldmann engaged in a prolonged political, public and personal struggle. ${ }^{57}$

55 For an example of such an approach, see the work of Richard Gottheil, Professor of Semitic languages at Columbia University and President of the American Federation of Zionists from 1898 to 1904, Richard J. Gottheil, Zionism (Philadelphia, 1914).

56 Lecture on Herzl delivered by Stephen Wise at a memorial assembly in memory of Herzl, New York, July 18, 1929, CZA, A-246/164. For a further lecture in similar vein, see Wise's address, The Epochal Herzl (undated, location unspecified), CZA, A-243/163.

57 For an extensive discussion of various aspects of this issue, see the articles in a volume on Goldmann, Mark A. Raider, "Idealism, Vision, and Pragmatism: Stephen S. Wise, Nahum Goldmann, and Abba Hillel Silver in the United States," in Mark A. Raider, ed., Nahum Goldmann, Statesman Without a State (Albany, 2009), 139-168; Zohar Segev, "Nahum Goldmann and the First Two Decades of the World Jewish Congress," in Raider, Goldmann, 107-124. The status of the WJC as an organization that adopted an independent political position which differed from that of the Zionist movement is manifested in the affair of the anti-German boycott in the United States. The WJC supported the boycott and opposed the "transfer" agreement concluded by the Zionist movement with the Nazi regime in the 1930s. For an extensive discussion of this issue, see Yfaat Weiss, “The Transfer Agreement and the Boycott Movement - A Jewish Dilemma on the Eve of the Holocaust,” Yad Vashem, Collection of Studies 26 (1998): 129-171. 
This outlook advocating the leverage of the Jewish community in the United States and throughout the world as a political force sharing common objectives became manifest in the launching of the World Jewish Congress in 1936. The timing of the inauguration was not coincidental. The accession of the Nazis to power in 1933 had accentuated the need for a Jewish organization devoted both to the struggle for the rights of Jews in their countries of residence and to institutional philanthropic activity on their behalf. Meanwhile, the plight of Central and Eastern European Jewry and the anti-Jewish propaganda emanating from Germany was enhancing the sense of Jewish solidarity and gradually motivating American Jews to act as an organized ethnic group in promoting Jewish goals. These developments generated a convenient platform for the operation of the Congress in the American arena, which was, at that time, the only sphere in which significant and politically powerful Jewish activity could be conducted.

The founders of the WJC noted on numerous occasions that the deterioration in the situation of European Jewry had served as a catalyst for the establishment of the organization. They referred to the imperative of countering the burgeoning Nazi propaganda, stressing that past solutions such as migration were no longer feasible. The reality of the thirties required organized, unified Jewish action of a political nature to an unprecedented extent. Those who formulated the founding position paper believed that international recognition of the necessity of a Jewish national home in Palestine as manifested in the Balfour Declaration and in resolutions of the League of Nations indicated a fundamental willingness to recognize the rights of the Jewish minority, and therefore in no way weakened-but even reinforced-international willingness to recognize the rights of Jews as a minority in Europe as well. The drafters of the paper pointed out the similarity of the processes whereby Jews were excluded in the various countries. They believed that this phenomenon demonstrated not a fundamentally nationalistic process, but rather an international phenomenon that necessitated an international Jewish response and a solution that transcended national borders. ${ }^{58}$ During a prepara-

58 See position paper of the Preparatory Committee of the World Jewish Congress in the United States, October 26, 1933, AJA, 361 A40/4, and a declaration of support by Louis Lipsky. Lipsky links the need for the organization to events in Europe. Lipsky's declaration, May 9, 1938, AJA, 361 A9/4. On the Congress's European activity during the 1930s, including its public activity against Germany, demonstrations in the United States, and meetings with the foreign ministers of Poland, Romania, Italy, and Czechoslovakia, see the classified survey of the WJC Executive's Political Activity, 1937, no specific date, AJA, 361 A5/1; memorandum on the topic of East European Jews submitted to the League of Nations, March 14, 1937, AJA, 361 A9/3. Regarding links with and support of the Polish opposition, see Goldmann's letter to Wise, May 1937 (no precise date), AJA, 361 A27/1. See also, Minutes of Meeting between Nahum Goldmann and the Polish Ambassador to Washington (which includes threats of anti-Polish activity in the United States if 
tory gathering of the WJC in the summer of 1934 in Geneva, Nahum Goldmann described the seriousness of the condition of German Jewry following the Nazis' accession to power, the wave of anti-Semitism washing over the world, and the grave plight of the Jews in Soviet Russia. He portrayed these developments as a dramatic series of events unprecedented in the annals of the Jews in modern times that called for an appropriate Jewish response, in which the establishment of the WJC would form the primary stratum. ${ }^{59}$ The heads of the WJC contended that the deep crisis in which European Jewry found itself made it imperative to set up a broad organization with an extensive, independent bureaucratic infrastructure. The WJC would open delegations in the main European capitals alongside the offices in the United States. Goldmann's and Wise's experience in the Zionist movement had taught them that in order to ensure its effectiveness, the new body would need to set up an administrative structure staffed by qualified people who drew a full salary. They believed that the failings of the Zionist movement to operate on behalf of the Jews of Europe stemmed in part from the fact that the organization was managed by volunteers, causing patterns of activity undertaken by some of the Zionist activists to be unsuited to Europe's changing reality in the mid-1930s. ${ }^{60}$

Rogers Brubaker has written about the complex challenges facing a voluntary organization that represents an ethnic minority dispersed among numerous countries. Such an organization strives to operate in a practical manner and to project itself to its surroundings as the exclusive representative of the majority of individuals who belong to the ethnic minority. According to Brubaker, such a situation cannot exist in reality for two reasons. First, the great variety that generally exists within the ethnic group precludes uniform representation; and second, members of ethnic groups dispersed throughout various lands are primarily concerned with existential problems that are not necessarily related to their groups' minority status. Even if the existential problems are linked to the reality of life within an ethnic minority, those needs differ significantly from country to country. Such varying needs may even be found among the members of the ethnic minority living in the same country, in accordance with their varied socio-eco-

its anti-Jewish policy were to continue), January 19, 1939, AJA, 361 A1/1; a description of activity in Europe, including meetings with various leaders in the United States, Britain, and with the Polish Government in Exile, cooperation with the Red Cross and other non-governmental organizations regarding the dispatch of provisions to Polish Jews; Classified Minutes of Meeting of Congress Functionaries in Europe, December 6, 1939, AJA, 361 A7/1.

59 See minutes of the opening meeting of the Congress's preparatory committee, August 8, 1936, AJA, 361 A40/5.

60 Letter from Goldmann to Wise, May 30, 1939, AJA, 361 A9/6. 
nomic status. ${ }^{61}$ The founders of the WJC were unfamiliar with Brubaker's thesis, but they had discerned that the story of 1930s European Jewry was a singular one, which enabled their organization to contend with the challenges confronting a representative international ethnic body. Their view was that the crisis of European Jewry resulting from its exclusion from all political, economic, cultural and social spheres of life had generated a different reality in which all Jews were confronting similar problems. This was a general phenomenon, which, unlike the circumstances of other minorities, called for a response that was ethnic in nature and that transcended national borders. German, Polish, and Romanian Jews were not subject to economic, political and social tribulations specific to their places of residence, but rather were confronting a pan-European phenomenon. Therefore, by contrast to other ethnic groups, the formation of an international Jewish body was an organizational and ideological response that was relevant to the Jewish condition in the latter half of the thirties.

The outbreak of World War II reinforced the WJC leadership's conviction that the organization was of vital importance to world Jewry. Nahum Goldmann referred to this in a lecture entitled "The Need for a World Jewish Congress," in which he asserted that those who refuted the need for an inter-Jewish international organization were blind to the events of the past decade and had learned nothing from them. He continued by maintaining that the idea of founding a world Jewish congress in the reality of the thirties was so obvious that it required no explanation. He strongly condemned those who argued that Jewish activity of an international nature was liable to raise doubts as to Jewish citizens' loyalty to their countries. Goldmann believed that these were groundless assertions that ran contrary to the patterns of international activity conducted by numerous bodies, from Socialists to Catholics. In his opinion, the fact that a significant part of the activity carried out by American Jews on behalf of their brethren was philanthropic in nature and involved primarily financial support, had transformed the Jewish issue from a political problem with which the world had to engage into an insignificant matter of welfare; but because of European Jewry's ghastly situation and despite the policy of philanthropy, the Jewish problem had become a major topic on the agenda of the world's leaders during the latter half of the 1930s. The problem of Europe's Jews was exceptionally serious since, unlike what was occurring in the Zionist context in Palestine, there was no entity representing the Jews of the world with which gainful contacts could have been established. This state of affairs had made it impossible to take effective action on behalf of

61 Rogers Brubaker, Ethnicity without Groups (Cambridge MA. and London, 2004), 22-24. 
the Jews. The WJC was designed to correct this failing and to constitute a representative body that would operate along the lines of the Zionist movement. ${ }^{62}$

Reports of the bitter fate of European Jewry under German occupation merely served to reinforce Goldmann's conviction regarding the necessity of the WJC. ${ }^{63}$ Although at this point he had not yet received reliable information about the Final Solution, Goldmann explained that whereas in the past only some of the Jewish communities in Europe had been subject to pogroms and the survivors had been able to rehabilitate themselves in a different community, this time the destruction was absolute and was occurring throughout Europe. The conclusion to be drawn from the terrible plight of European Jewry, he observed, was the need to turn the Jewish issue into a major European concern, and to explain that its solution must involve the entire world. The WJC was the sole Jewish organization able to lead the effort toward a solution of the Jewish problem at the international level. ${ }^{64}$ The subsequent information on the final solution and the methods of mass murder of the Jews of Europe served to bolster the Congress leaders' belief in the necessity for the WJC. Speaking to Jews in the United States in 1943, Wise proclaimed that Jews had responded to the Nazi challenge by closing ranks throughout the world. He stressed that American Jewry could not confront the Nazi challenge alone. Jewish unity in the United States was not sufficient, and it was now imperative to generate international cooperation and Jewish unity along the lines proposed by the WJC. ${ }^{65}$

The descendants of Jewish migrants from Eastern Europe, most of whom were Zionists, allied themselves with those of German and Central European origin who supported Jewish activity on a democratic basis. They were joined by European Jewish leaders who recognized the dominance of the American Jewish community on the eve of World War II, most of whom had immigrated to the United States in the second half of the 1930s and the early 1940s. These different groups formed a singular ethnic Jewish mix whose leaders supported the establishment of a Jewish state in Palestine, but did not regard it as the be all and end all. They saw themselves as the representatives of the Jewish world on the eve of World War II, during the hostilities, and thereafter, and as such they promoted the founding of a Jewish state as well as the rehabilitation of Jewish life in the Diaspora as two complementary objectives.

62 Goldmann lecture, The Need for a Jewish Congress (no location given), November 1941, no precise date, AJA, $361 \mathrm{~A} 5 / 3$.

63 Goldmann's lecture in New York, April 6, 1942, AJA, 361 A28/14.

64 Ibid.

65 Wise's address at the Council of American Jewry, New York, August 29, 1943, AJA, 361 A2/3. 